\title{
The Current Practices and Problems of School Based Supervision in Primary Schools of Jile Timuga Woreda
}

\author{
Defaru Geremew ${ }^{1}$ and Asrat Dagnew ${ }^{2^{*}}$
}

\author{
Jelie Timuga Woreda Education Office, Post Box No: 314, Oromia, Ethiopia
}

Faculty of Education and Behavioral Science, Bahir Dar University, Post Box No: 79, Bahir Dar, Ethiopia

\begin{tabular}{|c|c|}
\hline Abstract & Article Information \\
\hline $\begin{array}{l}\text { The purpose of this study was to identify the current practice and problems of school based } \\
\text { supervision in government primary schools of Jile Timuga Woreda of Oromia Zone. A } \\
\text { descriptive survey design of research methodology was employed. Regarding sampling, there } \\
\text { were } 39 \text { primary schools grouped in } 10 \text { cluster centres. From these cluster centres all were } \\
\text { selected using comprehensive sampling techniques. } 13 \text { primary schools were selected using } \\
\text { multi-stage sampling technique. Having these schools } 112(32.36 \%) \text { teachers was selected } \\
\text { out of } 342 \text { teachers using proportional stratified sampling followed by systematic random } \\
\text { sampling to select each teacher from the strata i.e. schools were considered as strata. This } \\
\text { constitutes } 56 \% \text { the respondents. All teacher respondents were used in the analysis. On the } \\
\text { other hand } 65 \text { school based supervisors, } 13 \text { principals and } 10 \text { cluster supervisors were } \\
\text { selected using comprehensive sampling techniques as they are highly responsible for } \\
\text { supervisory practices and their number was also manageable. The main instruments used to } \\
\text { collect data were questionnaire and semi-structured interview. The questionnaire was made to } \\
\text { be closed ended followed by some open ended questions and designed as five point Likert } \\
\text { scaled type. The reliability of the questionnaire was checked using cronbach alpha method } \\
\text { after pilot test was conducted. The face and content validity of the tools were also checked by } \\
\text { experienced experts in the study area. Frequency count and percentage were used for the } \\
\text { analysis of general characteristics of respondents. Mean and one sample t-test method of } \\
\text { analysis were used to analyse the data collected through questionnaire and also narration for } \\
\text { interview items. The results of the study reveal that the school based supervisory practice } \\
\text { were ineffective. School based supervisors were involved in the difficult task of supervision } \\
\text { without having sufficient training. School supervisors were also inefficient in promoting } \\
\text { professional competence of teachers. Furthermore, the study revealed that SBS was affected } \\
\text { by many problems that are related to the school itself, the supervisor and the clients } \\
\text { themselves. } \\
\text { Copyright@2015 STAR Journal, Wollega University. All Rights Reserved. }\end{array}$ & $\begin{array}{l}\text { Keywords: } \\
\text { Practices } \\
\text { Problems } \\
\text { Supervision } \\
\text { Primary School } \\
\text { *Corresponding Author: } \\
\text { Asrat Dagnew } \\
\text { E-mail: } \\
\text { asratboza@yahoo.com }\end{array}$ \\
\hline
\end{tabular}

\section{INTRODUCTION}

Schools are the formal agencies of education where the future citizens are shaped and developed through the process of teaching and learning. So schools need to help all students to develop their potential to the fullest level. This requires the effectiveness and commitment of the stakeholders particularly teachers, school leaders and management. (Aggarwal, 1985: 104). So schools must improve their basic functions of teaching process that aims at helping and empowering all students to raise their broad out comes through instructional improvement.

To achieve these expected outcomes, we need to have well selected curriculum and improved instructional situations and professionally motivated and competent teachers. In line with this, Mohanty (1990) stated that in educational system there are different variables that have their own contribution for its development of all, the one which is the main input and important is the teacher who needs effective instructional support. The relevant and quality education can be provided for the learners by engaging well-trained and professionally developed teachers at all levels of education. It is meaningless to build schools and distributed educational materials without effective and efficient human power that can transmit the educational contents to learners.

Awareness of teaching is empowering. The more interest teachers have in gaining awareness of how they teach, the more freedom they will have to direct their teaching towards successful student learning (Kral, 1996). To this effect, supervision is one of indispensable system of teacher's development. Supervision is a system of support mechanism that directly concerned on the development of staff members in a school or other institutions. 


\section{Defaru Geremew and Asrat Dagnew}

Today, modern concept of supervision has passed through its own evaluation, i.e., great changes have been observed over the years in the philosophy, objectives, functions, techniques and outcomes of supervision. The changes observed in the concept of supervision have resulted from the historical development and tradition of various educational systems (Eye and Netzer, 1965). The aims and functions of supervision, thus, vary according to the political and administrative structure of a country's education system, and the supervisory behaviour, practice and application of supervision are affected by political, social, religious and industrial forces existing at the time (Oliva and Pawlas, 1997).

The concept of supervision with respect to the contemporary educational thought is the total processes that include all duties and functions that are of high significance for the operation of a school system. At the same time supervision is a support system emphasizing with the development of teachers and students in the teaching and learning process. In professional terms supervision is an expert service which is based on accepted principles and planned program for the development of an institution (Serjovanni and Starrat, 1993). As it has been attributed by Harris in Oliva and Pawals (1997) supervision is comprehensively viewed as the complex part of an even complex institution in such a way that it is the total school function for analysing instructional process.

It is evident that recent years have exhibited decentralization of authority and responsibility down to local levels for the operations of school. This, decentralization has popularly been reorganized and given away to schools autonomy that significantly marked the value of school based management (Oliva and Pawlas, 1997). Such a recent phenomenon of School based management is based on supervision. According to these writers school based supervision is a practice subsequently resulting from school based management. School based supervision is characterized by share decision making and shared governance that involves empowering teachers, students, parents and other members of the school community. In such case, so, individual school will likely hold higher responsibility of providing instructional supervisory services to their respective communities (Oliva and Pawlas, 1997).

Account in the historical development of supervision in Ethiopia shows that the first three periods of inspection, supervision failed to provide the required services for teachers that develop their professional competence. This may be caused by the more inspectional and supervisory focus on administrative tasks than the teaching learning process (MOE, 1987). The fourth period that followed the downfall of the military government in 1991 has changed the focus of supervision following the new Education and Training Policy (ETP) that characterized reform from centralization to decentralization. This educational decentralization has also assigned schools authorities and responsibilities to make participatory school based decisions to improve the teaching and learning process. Thus, they are empowered with exercising such supervisory tasks as improving effectiveness in classrooms, enhancing professional competence of teachers, promoting learning achievement of students and improving their instructional systems and operation (MOE, 1994). Nowadays, the main actors of school based
Sci. Technol. Arts Res. J., Jan-March 2015, 4(1): 180-186

supervision in the schools are members of school supervision committee, principal, vice principals, unit leaders, department heads and experienced teachers supported by Woreda supervisory services (MOE, 1994).

The structure of school based supervision support services are relatively complex and most probably are related to instructional development, curriculum development and staff development affairs. Each of those domains includes several specific functions as coordination, consultation, group leadership and evaluation that need to perform. In addition to assessing the current practices the second concern of the study was finding out the problems those hinder the practice of school based supervisory activities for promoting and providing effective and efficient school based supervision. However, it is supervising that such issues are given little attention in most situations of the primary schools of Jile Timuga Woreda of Oromia Zone, there has been no research account made recently that show the current practice of school based supervision with respect to its practice as well as problems related to it in those primary schools of the Woreda..

Therefore, the study tried to investigate the current practices and problems of school based supervision in Primary schools of Jile Timuga Woreda of Oromia Zone and to answer the following basic questions.

1. What is the current practice of school based supervision look like in Primary schools?

2. What major problems have been facing the process of practicing school based supervision?

The general objective of this study was an assessment of the current practice and problems of school based supervision in government primary schools of Jile Timuga Woreda of Oromia Zone. Accordingly, this study focused on the following specific objectives that indicated the direction of the research work was to assess the current practice of school based supervision in terms of curriculum development, instructional development and staff development in the primary schools of Jile Timuga Woreda of Oromia Zone and to identify the major problems which have been facing in the processing of school based supervision.

\section{MATERIALS AND METHODS}

Descriptive survey research design was employed to assess the current practices and problems of school based supervision which was raised as the main issues of this study. The reason behind to choose this method was its usefulness and pertinent to explain the current practices without simplification or over exaggeration of authentic condition (Yalew, 2006). More over this research design enables the researchers to come up with valid conclusions of the study. This approach is helpful to collect descriptive information directly from the population to employ simple statistical techniques and to facilitate drawing generalization about large population on the basis of the study of representative samples. Besides, qualitative research methodology is employed as a supplementary to the study with the information gained from semi structured interview made with school principals and cluster supervisors.

\section{Source of Data}

The source of data for this study were teachers, school based supervisors, school principals and cluster 
Defaru Geremew and Asrat Dagnew

supervisors of primary schools in Jile Timuga Woreda of Oromia Zone.

\section{Population, Sample and Sampling Techniques Population}

There are 39 primary schools in Jile Timuga Woreda of Oromia Zone. The total population of this study was all teachers, school based supervisors, principals and cluster supervisors working in these 39 primary schools. In these 39 primary schools 684 teachers, 179 school based supervisors, 39 school principals and 10 assigned cluster school supervisors were working during the time of this study. Hence teachers, school based supervisors, school principals and cluster supervisors were the population of the study to which the target population and samples were taken from. The target population was 342 teachers, 65 school based supervisors, 13 principals, and 10 cluster supervisors.

\section{Sampling Techniques}

At the beginning of all tasks of sampling, list of all primary school was taken from the Woreda Education Office and their distribution was made to be proportional to take sample schools for each area of the woreda. For this, schools were organized in cluster and to take the selected schools, arrangement was made in their cluster. In case, there were 10 cluster centres in the Woreda. This contains about 3 to 4 schools in one cluster. From these 10 cluster centres, all cluster centres were taken by using comprehensive sampling techniques. Next to the above procedure all schools in the 10 cluster centres were listed by their name and arranged under their cluster. 13 schools were chosen using multi-stage sampling method from each cluster centres turn by turn.
Sci. Technol. Arts Res. J., Jan-March 2015, 4(1): 180-186

Regarding the selection of the sample teachers, list of teachers were prepared under each selected sample schools, proportion was made to take appropriate number of teachers based on number of teachers in each school and proportional stratified sampling followed by systematic random sampling method was employed to select the sample teacher. On the other hand, all school based supervisors, principals and cluster supervisors were taken as a sample using comprehensive sampling technique because they were useful to give information on the issue and their number was manageable.

\section{Instruments and procedures of Data Collection}

Gathering necessary data for the study was done by using questionnaire and interviews. In addition, relevant reference books, Journals, internet sources and supervision manuals were consulted to support the findings of the study.

In order to analyse the validity of the instruments, draft instruments of data collection were checked by two expertises Oromia Zone Education Department. In accordance with the suggestion from those experts, modification was made on the importance of items related to practices and problems of school based supervision. Furthermore, to check the reliability of each parts of the questionnaire coefficient of Cronbach alpha were calculated by SPSS after conducting a pilot test by taking 15 teachers and 5 school based supervisors who are outside the primary schools taken in the main study. The data obtained were taken to a statistician in Kemise College. The expert calculated the reliability using coefficient of Cronbach alpha shown for each part of the questionnaire found to be acceptable.

Table 1: The calculated Reliability values using Cronbach alpha method of Reliability Test

\begin{tabular}{clc}
\hline No & \multicolumn{1}{c}{ Item $\quad$ Reliability Items } & Calculated Reliability values \\
\hline 1 & Practice of SBS in Relation to Curriculum Development & 0.81 \\
2 & Practice of SBS in Relation to Instructional Development & 0.86 \\
3 & Practice of SBS in Relation to Staff Development & 0.83 \\
4 & Problems Related to Supervisors & 0.90 \\
\hline
\end{tabular}

\section{Techniques of Data Analysis}

After collecting the necessary data through different techniques, emphasis were given on the ways of organizing data as well as the application of some methodologies for analysis and discussing the data collected. The response collected through questionnaire was arranged in to meaningful figures, using frequency count for each respondents and percentage was used to analyse the general characteristics of respondents. Closed ended questionnaire items were analysed by using arithmetic mean and one sample T-test values. The arithmetic mean is calculated using the formula, $A \cdot M=\Sigma$ $f_{i} x_{i} / \sum f_{i}$ where $k=$ number of scales; $f_{i}=$ number of frequencies for each scales (responses); $x_{i}=$ value of classes ( $x_{1}=$ strongly agree, $x_{2}=$ Agree, $x_{3}=$ Uncertain, $\mathrm{x}_{4}=$ Disagree and $\mathrm{x}_{5}=$ strongly disagree) and $\sum \mathrm{f}_{\mathrm{i}}=\mathrm{n}=$ total number of respondents. The combined mean of all the observation in the two groups of respondents for each table can be calculated by adding the means for teachers and school based supervisors and dividing it by the number of items of each table. The mean calculated in this way is observed or calculated mean (OM). If a respondent only react to strong agreement or only react to strong disagreement the maximum and minimum value will be 5 and 1 respectively. By adding the two figures and dividing the sum by two $(5+1 / 2)$ the expected mean average "3" can be obtained. Data were analysed by determining the extent of difference and comparing OM with the EM. In addition to this the data collected through questionnaire on practices of school based supervision was arranged under each part of the questionnaire and the raw manually checked data were given to the statistician to calculate one sample t-test values and the results obtained were made for each part following procedures. Regarding the responses collected from interviewees, narration of qualitative was used after organizing them into practices and problems.

\section{RESULTS}

\section{One sample T-test for Practices of Curriculum} Development

The result of the respondents was merged together and on sample t-test was computed and the analysis is made and presented as follows. 
Table 2: One sample T-test for Practices of Curriculum Development

\begin{tabular}{|c|c|c|c|c|c|c|c|}
\hline \multirow{2}{*}{ Variable } & \multirow{2}{*}{ Respondents } & \multicolumn{6}{|c|}{ Test value $=3$} \\
\hline & & $\mathbf{N}$ & Mean & SD & t-value & Df & Sig(two tailed) \\
\hline Instructional & Teachers & 112 & 2.17 & 3.039 & -22.881 & 111 & 0.000 \\
\hline Development & School Based Supervision & 65 & 2.27 & 2.682 & -17.434 & 64 & 0.000 \\
\hline
\end{tabular}

As shown in table 2, the one sample t-test value of the practice of curriculum development mean score of teachers and school based supervisors is significantly lower than the mean test value $(t=-22.881, d f=111$, $\mathrm{p}=0.000$ and $\mathrm{t}=-17.434, \mathrm{df}=64, \mathrm{p}=0.000$ ) respectively. This shows that the practice of the curriculum development was at low level.

\section{One Sample T-test for Practices of Instructional Development}

The analysis is made by combining the results obtaining from the respondents in one and reported as follows.

Table 3: One sample T-test for Practices of Instructional Development

\begin{tabular}{|c|c|c|c|c|c|c|c|}
\hline \multirow{2}{*}{ Variable } & \multirow{2}{*}{ Respondents } & \multicolumn{6}{|c|}{ Test value $=3$} \\
\hline & & $\mathbf{N}$ & Mean & SD & t-value & Df & Sig(two tailed) \\
\hline Instructional & Teachers & 112 & 1.99 & 2.650 & -24.173 & 111 & .000 \\
\hline Development & School Based Supervision & 65 & 1.95 & 2.703 & -18.771 & 64 & .000 \\
\hline
\end{tabular}

In table 3 shown above the one sample t-test value for the practice of instructional development mean score of teachers and school based supervisors is significantly lower than the mean test value $(t=-24.173, d f=111, p=$ 0.000 and $t=-18.77, d f=64, p=0.000$ ) respectively. This shows that the practice of instructional development was not performed at the appropriate level.
One sample T-test for Practices of Staff Development

As indicated in table 4, the one sample t-test value of the practice of staff development mean score of teachers and school based supervisors is significantly lower than the mean $t$-test value $(t=-23.169, \mathrm{df}=111, \mathrm{p}=0.000$ and $t=-17.074, d f=64, p=0.000)$ respectively. This shows that the school supervisory activities in relation to the staff development were not practiced well as expected.

Table 4: One sample T-test for Practices of Staff Development

\begin{tabular}{|c|c|c|c|c|c|c|c|}
\hline \multirow{2}{*}{ Variable } & \multirow{2}{*}{ Respondents } & \multicolumn{6}{|c|}{ Test value $=3$} \\
\hline & & $\mathbf{N}$ & Mean & SD & t-value & Df & Sig (two tailed) \\
\hline Staff & Teachers & 112 & 2.00 & 2.724 & -23.169 & 111 & .000 \\
\hline Development & School Based Supervision & 65 & 2.01 & 2.797 & -17.074 & 64 & .000 \\
\hline
\end{tabular}

\section{Problems Related to Supervisors}

As indicated in table 5 item 1, respondent was asked whether school based supervisors are well trained in supervision to give skilled service or not. Majority of respondents agreed that school based supervisors are not well trained, because the OM for both respondents was 4.26 which is above the EM. Interview held with principals and supervisors also revealed the same answer. From these data it is possible to say that SBS is performed by untrained actors. Training keeps school based supervisors up to date and enhance their capabilities in order to provide guidance and counselling to teachers and also to fulfil new responsibilities (Dull, 1981). Likewise, UNICEF (2000) indicated that on-going school based supervision training is an influential instruments of SBS and can have a direct impact on students achievement. From the response and literature it can be generalized that, school based supervisors are not up to date and capable enough to provide supervisory support to teachers. Hence, untrained supervisors are problems in the practice of school based supervision.

Regarding item 2 of table 5, the OM for both respondents, for teachers and for school based supervisors is $3.91,4.04$ and 3.96 respectively. These figures show that majority of respondents agreed that School based supervisors did not create cooperative, honest, friendly and collegial relationship with and among teachers. Pajak (1989) pointed out that good supervisors are those who are capable of communicating with teachers to bring professional improvement. Hence, it can be said that, lack of cooperative, honest, friendly and collegial relationship is a problem related to supervisors that affect school based supervisory practices in the study area.

In the case of item 3 in the same table, the OM for both respondents 4.14 is greater than the EM. This means the majority of respondents confirmed the agreement that supervisors in the study area did not facilitate professional development through workshops, seminars and trainings. The interview result was also in line with data. This practice is against what has been discussed in the literature. Therefore, the absence of training, workshop and seminar facilitated by supervisors for professional development of teachers is one problem that affects school based supervisory practices.

As depicted in the same table of item 4, respondents agreed that failure of school based supervisors to help teachers evaluate curriculum materials and their own classroom performance is a problem related to supervisors that affected supervisory practices. Based on the result of the study the OM 4.09 for teachers, 4.01 for school based supervisors and 4.06 for both respondents is indicated agreement. This practice is different from what is indicated in the literature. 
Table 4: Responses in Relation to Problems to the Supervisors

\begin{tabular}{|c|c|c|c|c|}
\hline No & Items & Respondents & $\begin{array}{l}\text { Number of } \\
\text { respondents }\end{array}$ & Mean \\
\hline \multirow{3}{*}{1} & \multirow{3}{*}{$\begin{array}{l}\text { School based Supervisors are not well trained to assist } \\
\text { teachers. }\end{array}$} & Teachers & 112 & 4.25 \\
\hline & & School based supervisors & 65 & 4.29 \\
\hline & & Total & 177 & 4.26 \\
\hline \multirow{3}{*}{2} & \multirow{3}{*}{$\begin{array}{l}\text { Failure of school based supervisors to create cooperative, } \\
\text { honest, friendly and collegial relationship. }\end{array}$} & Teachers & 112 & 4.10 \\
\hline & & School based supervisors & 65 & 4.20 \\
\hline & & Total & 177 & 4.14 \\
\hline \multirow{3}{*}{3} & \multirow{3}{*}{$\begin{array}{l}\text { Absence of workshops, seminars and training arranged for } \\
\text { school based supervision to upgrade schools supportive } \\
\text { status. }\end{array}$} & Teachers & 112 & 4.09 \\
\hline & & School based supervisors & 65 & 4.01 \\
\hline & & Total & 177 & 4.06 \\
\hline \multirow{3}{*}{4} & \multirow{3}{*}{$\begin{array}{l}\text { Failure of school based supervisors to help teachers } \\
\text { evaluate curriculum materials }\end{array}$} & Teachers & 112 & 3.91 \\
\hline & & School based supervisors & 65 & 4.04 \\
\hline & & Total & 177 & 3.96 \\
\hline \multirow{3}{*}{5} & \multirow{3}{*}{$\begin{array}{l}\text { Failure of school based supervisors to assist teachers } \\
\text { conduct action research on instructional and other } \\
\text { educational problems. }\end{array}$} & Teachers & 112 & 4.17 \\
\hline & & School based supervisors & 65 & 4.43 \\
\hline & & Total & 177 & 4.27 \\
\hline \multirow{3}{*}{6} & \multirow{3}{*}{$\begin{array}{l}\text { In competence of school based supervisors in their skill } \\
\text { and experience in consulting teachers in curriculum, } \\
\text { instructional and staff development. }\end{array}$} & Teachers & 112 & 4.02 \\
\hline & & School based supervisors & 65 & 3.95 \\
\hline & & Total & 177 & 4.0 \\
\hline \multirow{3}{*}{7} & \multirow{3}{*}{$\begin{array}{l}\text { Failure of school based supervisors to facilitate the school, } \\
\text { parent and community relationship. }\end{array}$} & Teachers & 112 & 3.77 \\
\hline & & School based supervisors & 65 & 3.67 \\
\hline & & Total & 177 & 3.74 \\
\hline \multirow{3}{*}{8} & \multirow{3}{*}{$\begin{array}{l}\text { School based Supervisors had big work load and have no } \\
\text { enough time to provide supervisory services }\end{array}$} & Teachers & 112 & 4.07 \\
\hline & & School based supervisors & 65 & 4.16 \\
\hline & & Total & 177 & 4.10 \\
\hline \multirow{3}{*}{9} & \multirow{3}{*}{$\begin{array}{l}\text { Inadequate contribution of school based supervisors in } \\
\text { enhancing professional competence of teachers by } \\
\text { providing latest information on teaching strategies. }\end{array}$} & Teachers & 112 & 3.81 \\
\hline & & School based supervisors & 65 & 4.21 \\
\hline & & Total & 177 & 3.96 \\
\hline \multirow{6}{*}{10} & \multirow{3}{*}{$\begin{array}{l}\text { School based Supervisors are not able to provide } \\
\text { democratic professional leadership. }\end{array}$} & Teachers & 112 & 3.49 \\
\hline & & School based supervisors & 65 & 3.73 \\
\hline & & Total & 177 & 3.58 \\
\hline & \multirow{3}{*}{ Combined Mean } & Teachers & 112 & 3.96 \\
\hline & & School based supervisors & 65 & 4.03 \\
\hline & & Total & 177 & 3.99 \\
\hline
\end{tabular}

SBS=school based Supervision; EM=Expected Mean; OM=Observed Mean

Teachers and school based supervisors were asked to show the level of their agreement on the extent to which the failure of school based supervisors to assist teachers conduct research project on educational problems affect school based supervisory practices in their school. Regarding item 5 of the same table, majority of respondents showed their agreement, because the OM for both respondents is 4.27 which are greater than the EM. Interview held with principals and supervisors showed the same result. Hence, this item could be taken as one factor related to supervisors that affects SBS. As Dull (1981) pointed out, in service education at school level can be achieved through a number of ways such as research project, conferences, workshops, meetings, study groups, visiting other schools and classrooms. Emphasizing this Loeper (1969) pointed out that supervision and action researches are indispensable guardian of teacher's growth.

Regarding item 6 of table 5, respondents were asked to show the level of their agreement on the extent to which incompetence of school based supervisors affect SBS. The OM value for teachers 4.02 , for school based supervisors 3.95 and for both respondents 4.0are greater than the EM depicting agreement. These figures clearly indicated that school based supervisors' lack the necessary knowledge and skill in counselling teachers grow in their profession. As can be observed in item 7 of table 5, majority teachers and school based supervisors showed their agreement the OM for both respondents is 3.74 which are greater than EM value. Indicating that failure of school based supervisors to facilitate the school, parent and community relationship is a problem which affects the practice of school based supervision.

Item 8 of the same table shows that the response of teachers and school based supervisors, the big work load of school based supervisors is a problem that affects the practice of school based supervision or not. In this case the majority of respondents the OM 4.07 for teachers, 4.16 for school based supervisors and4.16 for both respondents were indicating agreement. Furthermore, the result obtained from interview confirms that most school based supervisors have more than 24 periods per week and MOE (1994) confirmed that big work load of members of school based supervisors affects the practice of SBS, because shortage of time hinders provision of adequate supervision and assigning enough supervisors.

The responses given to item 9 of table 5 , show that the OM for both respondents is 3.96 indicating agreement which reveals that inadequate contribution of school based supervisors in enhancing professional competence of teachers is one hindrance to school based supervision.

Response for item 10 in table 5, showed that respondents agreed that school based supervisors are not able to provide democratic professional leadership and this item is one of the actors which affect the practice of SBS. As per Johansson and Johansson (2000), teachers and supervisors should trust level are low group members will be dishonest and inconsiderable, in their 


\section{Defaru Geremew and Asrat Dagnew}

communication. The MOE (1987) has set down the principles that, supervision should be democratic and supervision is a process of giving friendly guidance and direction to teachers and pupil. Based on the value of combined mean, it might be possible to state that the School based supervisors rated the problems related to teachers is high.

Based on the value of combined mean, it might be possible to state that the School based supervisors rated the problems related to teachers is high.

In general, lack of training, workshop and seminars for School based supervisors and teachers, incompetence of School based supervisors, failure of School based supervisors to create cooperative, honest and collegial supervision, big work load of School based supervisors, failure of School based supervisors to help teachers grew in their profession and undemocratic leadership style of School based supervisors are the major problems that affects the practice of school based supervision

\section{DISCUSSION}

Educational supervision focus on the implementation of the three basic domains: curriculum, instructional and staff development. These domains are interrelated to each other. Staff development is developing and facilitating opportunities for professional growth. Teachers may undergo staff development within the instructional and curriculum development (Oliva and Pawlas, 1997). In general, the positive effect of activities which have been done in schools can be reflected through students' academic achievement might be the effective implementation of school based supervision. To this end, the practice of school based supervision was assessed in relation to curriculum, instructional and staff development.

\section{Practices of School Based Supervision in Relation to Curriculum Development}

Curriculum development is one of the basic domains of supervision which focus on designing and redesigning the guidelines for instruction including development of specifications what is to be thought, by whom, where, when, in what sequence or pattern( Oliva and Pawlas, 1997). In line with this, to assess the current practice of curriculum development eight items were prepared. The combined mean values of those eight items 2.15 for both respondents are lower than the expected mean. This shows that the practice of the curriculum development was at low level.

Moreover, Amlaku (2011) also indicated in his study that supervisory services in curriculum development were not sufficiently implemented in the school. Therefore, from the results of one sample t-test and the data obtained from the interview, one can conclude that the practices of school based supervision in schools under study have taken place without ensuring effective school based supervisory activities which affect the process of curriculum development.

\section{Practice of School Based Supervision in Relation to Instructional Development}

The three basic domains are interrelated to each other and their value rest on the improvement of the instruction. With regard to instructional development six items related to it were developed and assessed using arithmetic mean and also tested by using one sample t-test. The analysis
Sci. Technol. Arts Res. J., Jan-March 2015, 4(1): 180-186

is made by each items and the combined mean value 1.97 obtained from both respondents was lower than the expected mean. Furthermore, the result obtained from one sample t-test and the information obtained from the interview revealed that the practice of instructional development was not performed at the appropriate level.

From items indicated to taste the practices of instructional supervision, that are the school based supervisory activities should focus on incorporating the participation of those school actors as principals, teachers, students and parents, improving the teaching and instructional skills of the teachers, it should enhance teachers up to date methods of instructional activities, it should help services that are preventive, correcting and facilitating the instruction, and it also should assist teachers to become familiar with newer approaches to instruction were not well done in the schools. In consistent with this finding, Luel (2009) found in his study and reported as instructional supervision was not focused on knowledge, skill and attitudinal developments of the students.

\section{Practice of School Based Supervision in Relation to Staff Development}

The school staffs are comprised of teachers, principals and supervisors and other administrative bodies. Even though the degree of their contribution on the school based supervision improvement varies, they do have their own either positive or negative impact on the educational activities. From the outset, staff development focuses on training the goal of which is improvement of the person who makes up the school; with this regard 6 items related to staff development were given to respondents which are helpful to assess the practice of school based supervision in staff development. Those are school based supervisory activities encourage teachers for professional development, facilitate continuous professional development, arrange internal training programs that facilitate teaching and learning, encourage teachers to have high and meaningful expectation from students and improves human relation and cooperation among staff. The combined mean value 2.005 of those items is lower than the expected mean (EM). This shows that the school based supervisory activities in relation to staff development were not practiced well and as expected. Supporting this, the result of one sample t-test and response from interview also assured that the staff development was not practiced well as expected.

\section{Problems Related to Supervisors.}

As indicated in the literature of chapter two actors in the school based supervision may be cause by several factors and include the following value system of the supervisors. According to Sergiovanni and Starrat (1991) these are related to the approaches, behaviour styles, activities and characteristics displayed by the supervisors. Therefore, regarding the problems related to supervisors the findings of the study showed that the combined observed mean value 3.99 for both respondents were greater than the expected mean. This indicated that the problems in relation to supervisors in the practice of school based supervision were high. Furthermore, the information obtained from school principals and cluster supervisors assured that the problems related to supervisors were highly influenced the implementation of School based supervision activities. 


\section{Defaru Geremew and Asrat Dagnew}

\section{CONCLUSIONS}

The purpose of this study was to explore the practices and problems of school based supervision in Jile Timuga Woreda primary schools. To this effect data were collected and analyzed to find out the real practices and problems. To this end the following conclusion is given based on the findings of the study.

The summary of analysis revealed that supervisory practice is characterized by the failing state and has not been adequately practiced in promoting professional competence of teachers and improving teaching-learning process. More than this, the results obtained from mean and one sample t-test revealed that the practices of school based supervision in relation to curriculum, instructional, staff development were below the expected performance. Furthermore, respondents' view that school based supervision as poor in satisfying school community and teachers in supervisory support services and also the major problems that hampered the realization of effective implementation of school based supervision was identified and they were mainly problems related to the school itself, the supervisors and the clients. As the result of those potential problems it can be concluded that, the school based supervision is not given due consideration as a part of the educational program in the primary school of Jile Timuga Woreda of Oromia Zone. Moreover, it is indicated in the study and clearly perceived that all the main actors of school based supervision that were categorized under such groups as the school administrators, the supervisor and the clients, all are accountable to the currently inadequate practice and failing status of their respective school based supervisory practice because school based supervision is part of their daily instructional leader ship role.

\section{Conflict of Interest}

Conflict of interest none declared.

\section{REFERENCES}

Aggarwal. J. (1985). The Theory and Principles of Education: Philosophical and Sociological Bases of Education. New Dhallhi: Vikas Publishing House Pvt. Ltd.

Amlaku Ashenafi. (2011). The practice and problems of Instructional Supervision in Mecha Woreda Secondary
Sci. Technol. Arts Res. J., Jan-March 2015, 4(1): 180-186 schools: Unpublished Thesis, Bahir Dar University. Bahir Dar.

Dull, W. (1981). Supervision; school leadership hand book. Columbus: Charles, E. Merriel Publishing Company.

Eye, G.L.and Netzer,I.A(1965). Supervision of Instruction: A Phrase of Administration NewYork: Heaper and Low Publisher.

Johnsson, D.W and Johnsson, F.P. (2000). Administration of public Education ( $2^{\text {nd }}$ ed.).New York: Harper and Row publisher.

Kral,T.(1996). Teachers' development; making the right Moves Washington Dc: US information agency.

Loeper, R. C. (1969). Supervision Emerging profession and current development. Washington: NEA.

Luel Mekonen.(2009). The effectiveness of the cluster supervisory practice in primary schools at Awi Zone Administrative Woreda.

MOE (1987).Supervision Manual. Addis Ababa.

MOE (1994).The Education and Training Policy of Education. Addis Ababa: St.

Mohanty, B. (1990).School Administration and Supervision. New Dhel; Deep and Deep Publications

Oliva, P.F. and Pawlas, G.E. (1997).Supervision for Today's Schools. New York: Leryman Publisher.

Pajak,E.(1989). The central office supervision of Curriculum and Instruction setting the stage for success. Boston: Allyn and Bacon,Inc

Sergiovanni, T.J. and Starrat, K.S. (1991).Supervision a Redefinition. New York: Mc Graw Hill Inc.

Serjiovanni, T.J.and Staratt R.J. (1993). Supervision: A redefinition MA: McGraw-Hill.

UNICEF (2000).Defining Quality in Education. Working Paper Series, Program Division. New York: UNICEF

Yalew Endawoke. (2006). Basic Principles and Applications of Research Methodologies. Addis Ababa: Alpha Printing Press 